\title{
A FLEA BEETLE THAT FEEDS ON THE COMMON PLANTAIN
}

LARRY BURGESS, Agriculture Canada Research Station, Saskatoon, Saskatchewan, S7N 0X2.

Flea beetles are a group of leafeating beetles with enlarged hind legs and the ability to jump vigorously when disturbed. In the Prairie Provinces, while there are several species of flea beetles that are serious pests of rapeseed crops, mustard crops, and gardens, there are other species that live on native plants and have a more harmonious relationship with man. An interesting flea beetle in the latter category is Dibolia borealis Chev. (Fig. 1), a shiny black, convex beetle about 3 $\mathrm{mm}$ long with a bronzy or bluish sheen, whose host plant is the common plantain, Plantago major L. Hartley Fredeen of Saskatoon first drew this insect to my attention as unidentified adult flea beetles he had discovered feeding on plantains near the Fenton ferry southeast of Prince Albert. Since then Ed Wiens and I have observed this beetle feeding on plantain growing along trails in cutover areas of the boreal forest near Montreal Lake, Saskatchewan, and along the South Saskatchewan River at Saskatoon. I also observed them this past spring at Kenosee Lake in the southeastern corner of the province. Parry reports specimens from Fish Lake, Saskatchewan (location undetermined). ${ }^{3} \mathrm{~A}$ herbarium specimen of plantain collected from Maple Creek and in the Ralph C. Russell Herbarium of the Agriculture Canada Research Station in Saskatoon, contains leaf miner tunnels typical of $D$. borealis, and it is probable that this beetle occurs in Saskatchewan wherever the common plantain is present. To date in Saskatchewan I have seen $D$. borealis only on the common plantain, but further observations are necessary, as it has been found in Ontario that this beetle will feed and lay eggs on several plantain species. 1

Horn reported that $D$. borealis was widely distributed over the entire eastern United States and Canada, and also mentioned that one specimen in his collection was from Nevada. ${ }^{2}$ Parry, in a taxonomic revision of the genus Dibolia in America north of Mexico, examined specimens from the eastern half of United States and one from Montana, and from Alberta to Prince Edward Island and Nova Scotia in Canada. ${ }^{3}$

The life history of this beetle at Ithaca, New York, was described in detail by Helen Reed in 1927.4 In Saskatchewan, adult beetles are to be seen in May and June feeding on the surface of plantain leaves, with the feeding scars often developing into holes right through the leaves (Fig. 2). Each egg is laid in an individual depression chewed into the leaf surface, and upon hatching in late June or July, the minute larvae burrow into the leaves and become leaf miners. The tunnels created by the larvae between the two leaf surfaces are conspicuous and the larvae can often be seen within them (Fig. 2). After moulting twice the larvae leave the leaves and enter the ground where they pass through prepupal and pupal stages in small 


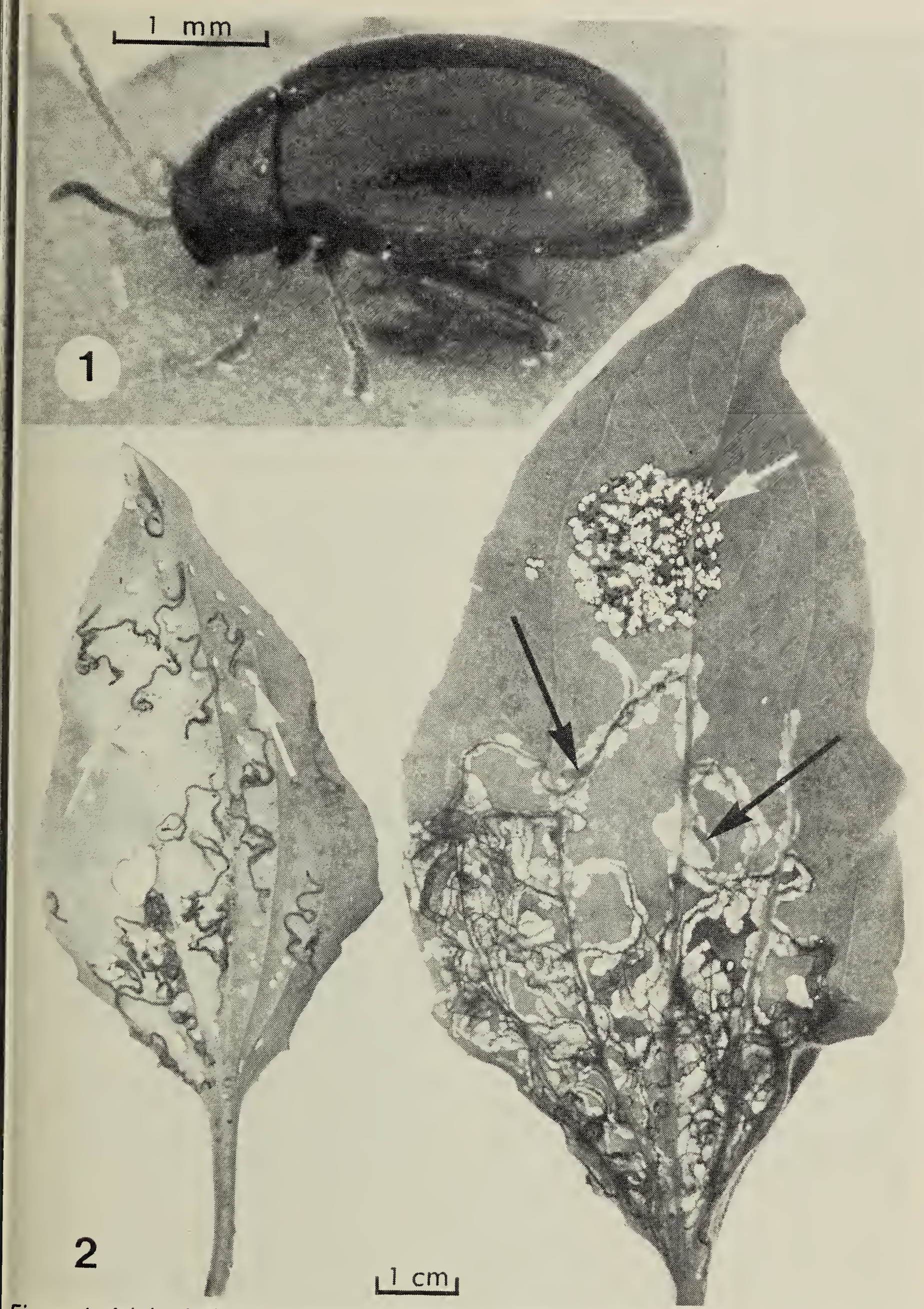

Figure 1. Adult of Dibolia borealis feeding on a plantain leaf.

Figure 2. Two plantain leaves showing larval tunnels, larvae (black arrows), and holes and feeding scars (white arrows) caused by feeding by adult D. borealis. The circular patterns of feeding scars near the tip of the larger leaf was caused by the adult beetles being confined to a glass vial.

Ralph E. Underwood 
earthen cells, and from whence the next generation of adult beetles emerge later in the summer. ${ }^{4}$ Reed believed that there was only a single generation per year in New York State, and the same situation is almost certainly true here, as is the case for all other flea beetle species we have studied in Saskatchewan. $D$. borealis is believed to overwinter as an adult and to become active again the following spring. ${ }^{4}$ We have not found any overwintering adults of $D$. borealis in extensive winter sampling of leaf litter and turf in the groves of trees that dot the Saskatchewan parkland although many overwintering adults of some other flea beetle species have been found in this habitat. Wilcox says that in Ohio adults of $D$. borealis may be found hibernating under the loose bark of sycamore trees. 5 Perhaps they overwinter in some similar habitat here, but as such habitats would be exposed to extreme winter temperatures perhaps they merely enter the soil or turf in the vicinity of plantains and thus pass the winter beneath a covering of snow. The few soil samples we have examined from around plantains in the fall have yielded no overwintering adults, and more sampling is needed.

Plantain leaves seem to withstand tunnelling and feeding by the beetles remarkably well; even a leaf as heavily damaged as that in Fig. 2 was still green and turgid at the apex. This is probably because both larval and adult feeding seem to leave the leaf veins more or less intact. This insect thus has a good parasitic relationship with its host plant in that it does not readily kill the plant and thus decrease its own chances of future survival.

\section{Acknowledgements}

I wish to thank Mr. J. E. Wiens for his assistance in these observations and Dr. D. G. Bright of the Biosystematics Research Institute, Agriculture Canada, Ottawa for identifying representative specimens. also thank Mr. Ralph E. Underwood for his kindness in taking the photographs.

1HAWTHORN, W. R. 1978. Some effects of different Plantago species on feeding preference and egg laying in the flea beetle Dibolia borealis Chev. (Chrysomelidae). Canadian Journal of Zoology 56: 1507-1513.

${ }^{2}$ HORN, G. H. 1889. A synopsis of the halticinae of boreal America. Transactions of the American Entomological Society $16: 163-320$.

3PARRY, R. H. 1974. Revision of the genus Dibolia Latreille in America north of Mexico (Coleoptera: Chrysomelidae). Canadian Journal of Zoology 52: 1317-1354.

${ }^{4}$ REED, HELEN 1927. Some observations on the leaf-mining fleabeetle Dibolia borealis Chevrolat. Annals of the Entomological Society of America 20: 540-549.

5WILCOX, J. A. 1954. Leaf beetles of Ohio (Chrysomelidae:Coleoptera). Ohio Biological Survey Bulletin 43 (Vol. 8(3): 353-506). 